\title{
Dietary protein, metabolism, and body-weight regulation: dose-response effects
}

Citation for published version (APA):

Westerterp-Plantenga, M. S., Luscombe-Marsh, N. D., Lejeune, M. P., Diepvens, K., Nieuwenhuizen, A. G., Engelen, M. P., Deutz, N. E., Azzout Marniche, D., Tome, D., \& Westerterp, K. R. (2006). Dietary protein, metabolism, and body-weight regulation: dose-response effects. International Journal of Obesity, 30 Supp/ 3, S16-23. https://doi.org/10.1038/sj.ijo.0803487

Document status and date:

Published: 01/01/2006

DOI:

10.1038/sj.ijo.0803487

Document Version:

Publisher's PDF, also known as Version of record

Document license:

Taverne

Please check the document version of this publication:

- A submitted manuscript is the version of the article upon submission and before peer-review. There can be important differences between the submitted version and the official published version of record.

People interested in the research are advised to contact the author for the final version of the publication, or visit the DOI to the publisher's website.

- The final author version and the galley proof are versions of the publication after peer review.

- The final published version features the final layout of the paper including the volume, issue and page numbers.

Link to publication

\footnotetext{
General rights rights.

- You may freely distribute the URL identifying the publication in the public portal. please follow below link for the End User Agreement:

www.umlib.nl/taverne-license

Take down policy

If you believe that this document breaches copyright please contact us at:

repository@maastrichtuniversity.nl

providing details and we will investigate your claim.
}

Copyright and moral rights for the publications made accessible in the public portal are retained by the authors and/or other copyright owners and it is a condition of accessing publications that users recognise and abide by the legal requirements associated with these

- Users may download and print one copy of any publication from the public portal for the purpose of private study or research.

- You may not further distribute the material or use it for any profit-making activity or commercial gain

If the publication is distributed under the terms of Article $25 \mathrm{fa}$ of the Dutch Copyright Act, indicated by the "Taverne" license above, 


\title{
Dietary protein, metabolism, and body-weight regulation: dose-response effects
}

\author{
MS Westerterp-Plantenga ${ }^{1,2}$, N Luscombe-Marsh ${ }^{1,2}$, MPGM Lejeune ${ }^{1,2}$, K Diepvens $^{1}$, \\ A Nieuwenhuizen $^{1,2}$, MPKJ Engelen ${ }^{2,3}$, NEP Deutz ${ }^{2,3}$, D Azzout-Marniche ${ }^{4}$, D Tome Thd $^{4}$ \\ KR Westerterp ${ }^{1,2}$
}

${ }^{1}$ Department of Human Biology, Nutrim, Maastricht University, MD Maastricht, The Netherlands; ${ }^{2}$ Wageningen Centre of
Food Sciences, Wageningen, The Netherlands; ${ }^{3}$ Department of Surgery, Nutrim, Maastricht University, MD Maastricht,
The Netherlands and ${ }^{4}$ Institut National de la Recherche Agronomique, Unité INRA-INAPG de Physiologie de la Nutrition
et du Comportement Alimentaire, Institut National Agronomique Paris-Grignon, F75231 Paris Cedex O5, France

Body-weight management requires a multifactorial approach. Recent findings suggest that an elevated protein intake seems to play a key role herein, through (i) increased satiety related to increased diet-induced thermogenesis; (ii) its effect on thermogenesis; (iii) body composition; and (iv) decreased energy-efficiency, all of which are related to protein metabolism. Supported by these mechanisms, relatively larger weight loss and subsequent stronger body-weight maintenance have been observed. Increased insulin sensitivity may appear, but it is unclear whether this is due to weight loss or type of diet. The phenomenon of increased satiety is utilized in reduced energy-intake diets, mainly in the ad libitum condition, whereby sustained satiety is achieved with sustained absolute protein intake in grams, despite lower energy intake. Elevated thermogenesis and glucagon-like peptide-1 (GLP-1) appear to play a role in high-protein induced satiety. Under conditions of weight maintenance, a high-protein diet shows a reduced energy efficiency related to the body composition of the body weight regained, that is, in favor of fat-free mass. Indeed, during body-weight loss, as well as during weight regain, a high-protein diet preserves or increases fat-free mass and reduces fat mass and improves the metabolic profile. In the short-term this may be supported by a positive protein and a negative fat balance, through increased fat oxidation. As protein intake is studied under various states of energy balance, absolute and relative protein intake needs to be discriminated. In absolute grams, a normal protein diet becomes a relatively high-protein diet in negative energy balance and at weight maintenance. Therefore, 'high protein negative energy balance diets' aim to keep the grams of proteins ingested at the same level as consumed at energy balance, despite lower energy intakes.

International Journal of Obesity (2006) 30, S16-S23. doi:10.1038/s.ijo.0803487

Keywords: body-weight regulation; body composition; thermogenesis; substrate oxidation; energy efficiency; protein metabolism

\section{Introduction}

Obesity, with its co-morbidities such as the metabolic syndrome and cardiovascular diseases, is one of the major biomedical problems of the last decades. Efficient, effective and satisfying treatments are necessary. The system of body-weight regulation shows a high degree of redundancy: when one pathway is modulated, another one appears to compensate, at least in part. ${ }^{1}$ Therefore, it is imperative to find a treatment that affects different short- and long-term mechanisms. We

Correspondence: Dr MS Westerterp-Plantenga, Department of Human Biology, Nutrim Maastricht University, P O Box 616, 6200 MD Maastricht, The Netherlands.

E-mail: M.Westerterp@hb.unimaas.nl suggest that an elevated protein intake may serve this purpose because of its: (i) increased satiety effect despite similar or lower energy intake; ${ }^{2,3}$ (ii) contribution to storage of fat-free mass(FFM); ${ }^{4-6}$ and (iii) low energy efficiency during overfeeding. ${ }^{7,8}$ The low energy efficiency may, in part, be owing to the increased thermogenesis and/or the composition of the body-mass gained (i.e. storing energy as FFM is more costly than as fat mass (FM)). ${ }^{9}$ Although studies have confirmed that these mechanisms contribute to greater weight loss and more sustained body-weight maintenance discrepant results between studies appear to be owing to the quantity of protein consumed. Accordingly, 'low', 'normal' and 'high' protein contents must be clearly defined. Furthermore, as it has been suggested ${ }^{10}$ that protein metabolism may play a role in satiety and thermogenesis, this too will be discussed. 


\section{Absolute or relative 'normal' and 'high' protein diets}

The World Health Organization, recommends that dietary protein should account for $\sim 10-15 \%$ of energy when in energy balance and weight stable. ${ }^{11}$ Average daily protein intakes in various countries indicate that these recommendations are reflective of what is being consumed worldwide. ${ }^{12-16}$ Protein intake may be expressed in grams or as percentage of energy intake. When advising subjects to consume a highprotein diet, the difference between these two measures should be taken into account. For instance, a weight loss diet of $2.5 \mathrm{MJ} /$ day with a protein content of $60 \mathrm{~g}$ /day consists for $40 \%$ of energy of protein, whereas an energy-balance diet of $10 \mathrm{MJ} /$ day with $60 \mathrm{~g} /$ day protein contains $10 \%$ of energy of protein. To ensure that subjects are not in a negative nitrogen and protein balance during weight loss, and therefore lose their metabolically active FFM, the absolute amount of protein is of greater importance than the percentage of protein. Varying the protein content of a formula diet from 0 to $50 \mathrm{~g} /$ day resulted in a protein loss varying between 91 and $1202 \mathrm{~g}$ measured over 28 days, respectively. ${ }^{17,18}$ The fat loss as percentage of total weight loss varied from $43 \%$ with $0 \mathrm{~g}$ /day protein, up to $79 \%$ with $50 \mathrm{~g} /$ day protein. ${ }^{18}$ These results indicate that a higher protein intake changes body composition in a way that spares FFM. Similarly, when weight maintenance after weight loss is sustained, FFM is preserved. FM still reduces and FFM increases on a relatively high-protein diet, that is, $18-25 \%$ of energy intake, which is in absolute terms $60-75 \mathrm{~g}$ /day protein. As weight maintenance after weight loss usually implies a slight weight regain, Stock's model can be applied. ${ }^{7}$ Here, the greatest metabolic efficiency of weight gain is shown when protein intake is $10-15 \%$ of energy during overfeeding, and inefficiency is shown with $<5 \%$ and $>20 \%$ of energy from protein. The latter metabolic inefficiency is related to the body composition. To build $1 \mathrm{~kg}$ body weight with 60\% FM and $40 \%$ FFM, $30 \mathrm{MJ}$ needs to be ingested additionally, whereas to build only $1 \mathrm{~kg}$ FFM 50-70 MJ is needed additionally. ${ }^{7,9}$ Therefore, a high-protein diet may promote weight maintenance by its metabolic inefficiency because of the cost involved in sparing FFM. Taken together, an absolutely normal protein diet of $60 \mathrm{~g} /$ day as ingesting $10 \mathrm{MJ} /$ day becomes a relatively highprotein diet in a negative energy balance of $2.5 \mathrm{MJ} /$ day (i.e. $40 \%$ of energy) and at weight maintenance of $5 \mathrm{MJ} /$ day (i.e. $20 \%$ of energy). Therefore, recommendations of 'high protein negative energy balance diets' only imply to keep the grams of proteins ingested at the same level, that is, representing 10$15 \%$ of energy at energy balance, despite lower energy intakes.

\section{The satiating effect of protein}

A hierarchy has been observed for the satiating efficacies of the macronutrients protein, carbohydrate and fat, with protein as most satiating and fat as least satiating. At the same time, a priority is shown with respect to the magnitude of the rate at which these macronutrients are metabolized. ${ }^{2,19,20}$ In the controlled environment of a respiration chamber, satiety and metabolic rate, with high- vs normalprotein diets (protein $(\mathrm{P}) /$ carbohydrate $(\mathrm{C}) /$ fat $(\mathrm{F}): 30 / 60 / 10$ vs $10 / 30 / 60 \%$ of energy (en\%)), was assessed over $24 \mathrm{~h}$ whereas subjects were in energy balance. Throughout the day, and in between meals, satiety and fullness were higher on the absolute high-protein diet, whereas hunger, appetite, desire to eat and estimated quantity to eat, were lower than on the normal protein diet. Only on the high-protein diet was satiety positively related to $24 \mathrm{~h}$ diet-induced thermogenesis (DIT). The theoretical basis of this relationship between satiety and DIT may be that increased energy expenditure at rest implies an increased oxygen consumption and an increase in body temperature that may be lead to feeling deprived of oxygen and translated into satiety feelings. ${ }^{2}$ This idea is in line with higher satiety scores under limited oxygen availability conditions, as observed at high altitude and in COPD patients, who also very quickly feel deprived of oxygen when feeding. ${ }^{21}$ Subsequently, in a similar respiration chamber experiment, several mechanisms of protein-induced satiety were assessed simultaneously. ${ }^{3}$ Lean women were fed in energy balance an adequate-protein (10 en $\%$ P (i.e. $\sim 60 \mathrm{~g}$ ) $/ 60$ en $\% \mathrm{C} / 30$ en $\% \mathrm{~F}$ ) or an absolute high-protein (30 en\% protein i.e. 180 g)/40 en\% C/30en $\%$ F) diet for 4 days. Results showed that the high-protein diet compared to the adequate-protein diet when eaten over 4 days increased the 24-h satiety and decreased hunger, without differences in energy intake. This supports the hypothesis that protein increases satiety to a higher extent than does carbohydrate or fat. The finding was also reflected in the relationship between $24 \mathrm{~h}$ satiety and protein intake, which was seen only in the absolute high-protein diet. The protein intake during the high-protein diet $(2.6 \pm 0.3 \mathrm{~g} / \mathrm{kg})$ resulted in a positive protein balance, whereas the protein intake during the adequate-protein diet $(1.0 \pm 0.1 \mathrm{~g} / \mathrm{kg})$ resulted in a protein balance that was not significantly different from zero. Thus, when protein intake exceeds the protein requirement, satiety is positively related to absolute protein intake. Simultaneously, measurements of the bloodparameters ghrelin and GLP-1 were executed throughout the day, showing no difference in ghrelin concentrations between diets. GLP-1 concentrations after dinner, however, were significantly higher on the high-protein diet. $^{3}$ Thus, when lean women ingested identical amounts of energy and volume, in identical meal patterns and comparable foods with respect to the organoleptic characteristics and in energy balance, a difference in the satiety level owing to an absolute high-protein vs an adequate-protein diet was related to a difference in the 24-h DIT component of energy expenditure, to the absolute amount of protein ingested, and coincided with the increased GLP-1 concentrations after dinner. $^{2,3}$

Related to the protein metabolism, evidence for differences in short-term satiety between protein from different 
sources (i.e. whey and casein) has been shown. ${ }^{10}$ Postprandial satiety appeared to be larger after a whey-preload than after a casein-preload, and was related to more elevated concentrations of amino acids in the blood as well as with greater elevation of both cholecystokinin and GLP-1. ${ }^{10}$

The digestion and absorption of whey and casein differ in that casein, unlike whey, coagulates in the stomach owing to its precipitation by gastric acid. ${ }^{22}$ As a result, overall gastric emptying time for casein appeared to be longer and a smaller post-prandial increase in plasma amino acids compared with the non-coagulating whey protein was observed. The peak total amino-acid concentration after whey ingestion occurs within 30-45 min; whey protein is a highly digestible protein. $^{22,23}$ In contrast, after the intake of the slowly absorbed casein, the increase in the plasma total amino-acid concentrations is less. Rapid increase of amino-acid concentrations after a meal is related to stimulation of oxidation and protein syntheses. ${ }^{22-24}$

In a longer term study, Weigle et al. ${ }^{25}$ showed the satiating effect of a high-protein diet was increased when the highprotein diet (30 en\% P ( 180 g), 20 en\% F, 50 en\% C) was fed iso-energetically to the normal protein diet (15 en\% $\mathrm{P}(\sim 90 \mathrm{~g}), 35 \mathrm{en} \% \mathrm{~F}, 50 \mathrm{en} \% \mathrm{C})$ for 2 weeks in energy balance of $\sim 10 \mathrm{MJ} /$ day. Thereafter, a reduction in energy intake with $\sim 2 \mathrm{MJ} /$ day was observed, when the high-protein diet was offered ad libitum, achieving the previous level of satiety at the same time. Although the diet was still relatively high in protein (30 en\%), the absolute amount being reduced to $\sim 144 \mathrm{~g}$ was sufficiently high to sustain satiety at the original, probably desired level, as decreasing energy intake. $^{25}$

In rats, protein was also shown to be more potent than carbohydrate for reducing appetite, in a dose-dependent manner. The animals were more satiated by protein when the proportion was $35-50 \%$, than by carbohydrate. However, the animals had to learn the post-ingestive effects of the loads before the response stabilized. The authors concluded that in rats, the larger the protein proportion of the food, the larger is the satiating effect, The quality of protein did not seem to play a significant role, ${ }^{26}$ and neither did conditioned taste aversion. $^{27}$

In conclusion, evidence is shown for protein being more satiating than carbohydrate and fat, in short term, over $24 \mathrm{~h}$ and, in the long term. Absolute amount of protein given, elevations in GLP-1 concentrations, thermogenesis and protein metabolism appear to play a role in the satiety effect. This may however differ between different protein sources.

\section{Thermogenic effects of proteins}

The metabolizable energy of protein, as defined in the Atwater factor, is $17 \mathrm{~kJ} / \mathrm{g}$. However, protein is particularly thermogenic and the net metabolizable energy is actually
$13 \mathrm{~kJ} / \mathrm{g}$, making it lower than either carbohydrate or fat. ${ }^{28}$ The thermic effect of nutrients is related to the stimulation of energy-requiring processes during the post-prandial period. It is based on the amount of ATP required for the initial steps of metabolism and storage. Reported values for separate nutrients are $0-3 \%$ for fat, 5-10\% for carbohydrate and $20-30 \%$ for protein. ${ }^{29}$ Thus, a high-protein diet induces a greater thermic response in healthy subjects compared to a high-fat diet. ${ }^{30}$ This even implied a higher fat oxidation, thus a negative fat balance and a positive protein balance. ${ }^{3}$

The relatively strong thermic effect of protein may be mediated by the high ATP costs of post-prandial protein synthesis. ${ }^{31,32}$ Additionally, amino-acid oxidation may also play a major role, especially when amino acids are given in excess of protein deposition. In elderly women, increasing the amount of dietary protein from 10 to $20 \%$ energy resulted in a $63-95 \%$ increase in protein oxidation, depending on the protein source. ${ }^{33}$ The largest $(95 \%)$ increase in protein oxidation was observed when the predominant protein source was of animal origin, whereas this increase was only $63 \%$ when soy protein was the predominant dietary protein source. ${ }^{33}$ Accordingly, Mikkelsen et al. observed a higher DIT with pork meat than with soy protein. ${ }^{34}$

The studies cited above indicate that protein metabolism and, consequently, energy expenditure is dependent on the protein source. An important factor that determines postprandial protein metabolism is its digestion rate. Thus, ingestion of rapidly digested protein, such as whey, results in a stronger increase in post-prandial protein synthesis and amino-acid oxidation than slowly digested protein, such as casein. ${ }^{35-37}$

The amino-acid composition of the protein may also be an important determinant of the metabolic efficacy of protein oxidation (hence, heat production) because large differences exist in the efficacy with which amino acids are oxidized. This is due to the large variety of carbon chains and cofactors that result from amino-acid catabolism. ${ }^{32,38}$ For instance, the number of amino groups that undergo conversion to urea in the urea cycle, at a cost of four ATP, ranges from one for an amino acid such as proline or alanine, to three for histidine. ${ }^{32,38}$ Therefore, taking into account the stoichiometry of amino-acid catabolism and urea synthesis, the calculated energy expenditure to produce ATP is ranging from $153 \mathrm{~kJ} /$ ATP for cysteine, to $99 \mathrm{~kJ} / \mathrm{ATP}$ for glutamate. For glucose, this value is $91 \mathrm{~kJ} / \mathrm{ATP}^{32}$

\section{Gluconeogenesis}

De novo synthesis of glucose from gluconeogenic precursors is stimulated when glucose availability is reduced during fasting or with a low or carbohydrate-free diet, and is also increased by a high-protein diet. ${ }^{39-41}$ This effect on gluconeogenesis could be involved in the satiating effect of protein through a modulation of glucose homeostasis and glucose signaling to the brain. 
The main gluconeogenic organ is the liver. The activity of hepatic phosphoenolpyruvate carboxykinase (PEPCK), an enzyme involved in gluconeogenesis, is increased in rats fed a high-protein diet. This effect is observed with diet containing protein or not carbohydrates suggesting that the level of protein per se in the diet is able to stimulate hepatic gluconeogenesis. ${ }^{42,43}$ Interestingly, when increasing the protein content of the diet, PEPCK (which controls the initial conversion of oxaloacetate to phosphoenolpyruvate) is upregulated either in the fasted and in the fed state, whereas glucose 6-phosphatase (G6Pase) (which controls the last step of gluconeogenesis) is upregulated in the fasted state and downregulated in the fed state. ${ }^{43,44}$ These observations strongly suggest that liver gluconeogenesis is stimulated by a high-protein diet but that in the fed state the newly synthesized glucose 6-phosphate (G6P) is directed toward glycogen synthesis whereas in the fasted state it is converted to glucose and released from hepatocyte. The control of PEPCK and G6Pase activity in the liver by nutrients has a profound impact on hepatic metabolism and glucose homeostasis $^{45,46}$ and the satiating effect of high-protein feeding could be related to the improvement of glucose homeostasis through the modulation of hepatic gluconeogenesis and subsequent glucose metabolism.

A stimulation of intestinal gluconeogenesis and glucose portal sensing through portal vagal afferent fibres has also been proposed as an alternative hypothesis for the elevated satiety related to a high-protein diet. ${ }^{47}$ However, the depressant effect of a high-protein diet was not abolished after vagotomy in the rat. ${ }^{48}$ Moreover, the relevance and physiological significance of intestinal gluconeogenesis remains a subject of debate. ${ }^{49}$ Firstly, the expression of the genes encoding PEPCK and G6Pase is very low in the intestine and only represents 0.5 and $6.5 \%$ of the mRNA abundance found in the liver, respectively. ${ }^{50,51,44}$ Moreover, despite a slight increase in enzyme activities, no changes in intestinal PEPCK and G6Pase protein and mRNA abundance could be observed in rats fed a high-protein diet ${ }^{52}$ or after 5 days fasting. ${ }^{53}$ In addition, the small intestine has been classified as a gluconeogenic organ because of the expression of the G6Pase in this tissue, ${ }^{54,55}$ but this is mainly due to expression of the ubiquitous G6PC3 isoform catalytic subunit, which is 8-19-fold higher than the expression of the gluconeogenic G6PC1 isoform in the intestine. ${ }^{44}$ Taken together, these observations do not support portal sensing of glucose produced from intestinal gluconeogenesis as the main mechanism involved in the effect of high-protein feeding on food intake.

\section{Insulin sensitivity}

The post-prandial pattern of plasma amino acids may be an important entity for the insulinogenic properties of food proteins. The insulin stimulating effect of proteins may be mediated through specific amino acids released during digestion. Several amino acids are potent stimulators of insulin release, and certain amino acids (e.g. leucine, arginine, phenylalanine and tyrosine) are more insulinogenic than are others. ${ }^{56,57}$ The magnitude and the duration of changes in amino acid and insulin availability determine the anabolic effects. It is however unclear whether the composition of dietary protein has a positive or negative impact on glycemic control.

Aerobic and/or resistance exercise increase insulin sensitivity as well as the ability of protein/amino acid intake to stimulate muscle anabolism. ${ }^{58,59}$ Exercise accelerates muscle protein turnover; however, stimulation of protein synthesis exceeds activation of proteolysis. ${ }^{60}$ The rate of muscle protein synthesis is increased up to $48 \mathrm{~h}$ after a resistance exercise session. ${ }^{61}$ The kinetic and regulatory properties of dietary protein may enhance the ability of aerobic and/or resistance exercise to regulate glucose metabolism and enhance protein anabolism. By preventing excessive stimulation of proteolysis after exercise, for example, with rapidly absorbed whey protein, the exercise effects on glucose control may be improved. In addition, slowly absorbed casein protein may enhance and prolong for several hours the stimulation of muscle protein synthesis after each exercise session. Also leucine is known to stimulate insulin release. ${ }^{62}$ Leucine seems to be an important regulator of muscle protein synthesis. ${ }^{63}$ Leucine appears to regulate oxidative use of glucose by skeletal muscle through stimulation of glucose recycling via the glucose-alanine cycle and, thus is (in)directly linked to protein sparing and glycemic control. Protein sparing during restricted energy intake could be improved by enhanced dietary leucine intake. Leucine infusion in obese subjects may induce protein sparing. ${ }^{64}$

Short and longer-term feeding studies (6-12 months) examining the effect of increased protein diets on the insulin sensitivity of obese, but not diabetic, individuals have been performed and as the findings appear favorable, they remain inconclusive. Over 21 days, Piatti et al. ${ }^{65}$ compared two energy-restricted (3.3 MJ/day), low-fat (20\% of energy) diets with either 45 or $20 \%$ of energy as protein ( $\sim 82$ vs $36.6 \mathrm{~g} /$ day), in 25 obese hyperinsulinaemic women. A significant improvement in insulin sensitivity after weight loss was observed on the higher-protein diet (after an euglycaemic, hyperinsulinaemic clamp, glucose oxidation significantly increased by $0.55 \mathrm{mg} / \mathrm{kg} \mathrm{FFM} / \mathrm{min}$ and the rate of disappearance of glucose significantly increased by $2.10 \%$ over the basal rate). No improvement was found with the lower protein diet (glucose oxidation was reduced by $0.55 \mathrm{mg} / \mathrm{kg} \mathrm{FFM} / \mathrm{min}$ and the rate of disappearance of glucose was reduced by $11.5 \%$ over the basal rate). They proposed that the improvement in insulin mediated glucose uptake in skeletal muscle resulted from the observed preservation of lean body mass after weight loss. Lean mass was on average reduced by $3 \mathrm{~kg}$ on the lower protein diet as compared to only $1.4 \mathrm{~kg}$ on the higher-protein diet. ${ }^{65} \mathrm{Baba}$ 
et $a l .{ }^{66}$ also reported that mean fasting insulin concentrations of hyperinsulinaemic men were reduced to within the normal range, (HP group, reduced from 38 to $20.5 \mu \mathrm{U} / 1$ vs NP group, reduced from 41.5 to $27.4 \mu \mathrm{U} / \mathrm{l}$ ), after 4 weeks of weight loss $(2.3 \mathrm{~kg}, 38 \%)$ on iso-energetic high as compared to normal protein diets ( 45 en $\% \mathrm{P}$ ( 183 g/day) vs $12 \mathrm{en} \% \mathrm{P}$ ( $\sim 49 \mathrm{~g} /$ day), 30 en\% F, $\sim 7.3 \mathrm{MJ} /$ day). In contrast, despite findings that FFM loss was smaller in the group consuming a high-protein diet, neither Farnsworth et al. ${ }^{67}$ nor Layman et al. ${ }^{68}$ found that increased protein enhanced insulin sensitivity independent of weight loss. Farnsworth et al. ${ }^{67}$ reported that although total lean mass in hyperinsulinaemic women, but not men, was better preserved with the high protein $(27 \%, \sim 90-110 \mathrm{~g} /$ day) as compared to normal protein (16\%, 53-62 g/day) diet, no differential improvement in insulin resistance was conferred.

Over the longer-term, Samaha et al. ${ }^{69}$ observed that insulin sensitivity was improved more (6 vs $-3 \%, P=0.01$ ) among 81 obese, non-diabetic, men and women following a high as compared to normal protein $(16 \%(\sim 59 \mathrm{~g} /$ day $)$ vs $22 \%$ ( $\sim 83 \mathrm{~g} /$ day), ) diet and these improvements remained for 6 months. In contrast, in the 12-month follow-up to Farnsworth et al.'s study, ${ }^{67}$ Brinkworth et al. ${ }^{70}$ reported that both the 15 and $30 \%$ protein, low-fat diets resulted in a sustained reduction in fasting insulin levels and HOMA in 43 hyperinsulinaemic individuals. Although the insulin levels were moved towards normalization, the approximate $40 \mathrm{~g}$ / day difference in protein intake resulted in no greater benefits on insulin sensitivity. In fact, it was concluded that a sustained fat loss and preservation of FFM was responsible for the improved insulin resistance. Confirming these findings, Brehm et al. ${ }^{71}$ also saw no difference in the fasting insulin concentrations of 53 obese women after a higher as compared to lower protein weight loss diet (23-25 en\% P ( $\sim 65 \mathrm{~g} /$ day) vs $\sim 18$ en\% P ( $\sim 52 \mathrm{~g} /$ day $)$ ) over 6 months. What is clear from the literature is that energy restriction and weight loss both have independent effects on insulin sensitivity. Further research however is warranted to determine whether increased dietary protein and what quantity, in absolute grams per day, has sustained beneficial effects on the insulin sensitivity of obese individuals.

\section{Relatively high-protein diets for body-weight loss}

Relatively high-protein diets for body-weight loss have been assessed during different periods of time. A relatively highprotein diet was compared with a control diet in order to evaluate weight loss over 6 months, when energy intake was ad libitum. ${ }^{72}$ The effects of $25 \%$ vs $12 \%$ energy intake from protein (45 en\% C, 30 en\% F vs 58 en\% C, 30 en\% F) on weight loss in obese subjects (body mass index $(\mathrm{BMI})=30$ $\mathrm{kg} / \mathrm{m}^{2}$ ) was examined. It was found that weight loss (8.9 vs $5.1 \mathrm{~kg}$ ) and fat loss (7.6 vs $4.3 \mathrm{~kg}$ ) were higher in the high-protein group, owing to a lower energy intake (5.0 vs
6.2 MJ/day, $P<0.05) .{ }^{72}$ Again, here $25 \%$ of energy from protein at an intake of $5 \mathrm{MJ} /$ day implies $75 \mathrm{~g}$ of protein. In a follow-up study it was observed that after 12 months the weight loss was not significantly greater among the subjects in the high-protein group, but they had a greater reduction in intra-abdominal adipose tissue. ${ }^{73}$ Also a favourable effect of a high-protein diet on body weight was found during 6 days ad libitum feeding. ${ }^{74}$ The low-glycaemic index low-fathigh-protein diet resulted in a spontaneous decrease in energy intake of $25 \%$ compared to a high-carbohydrate-lowfat diet (8.8 vs $11.7 \mathrm{MJ} /$ day), in the ad lib situation. In addition, the metabolic profile was considerably improved. ${ }^{74}$ Body-weight loss was $2.3 \mathrm{~kg}$ over 6 days compared to no weight loss on the high-carbohydrate diet. ${ }^{74}$ However, in comparison to an iso-energetic high-carbohydrate diet, there was no significant difference in body-weight loss. ${ }^{74}$ An improved body composition owing to a reduced ratio of dietary carbohydrate to protein and improved blood lipid profiles was found during weight loss in adult women. ${ }^{75}$ However, weight loss on the high-protein diet was not different from the control group; probably owing to the lack of difference in energy intake. This phenomenon was confirmed again by Weigle et al. ${ }^{25}$ who first served 19 subjects in a controlled situation an iso-energetic highprotein diet (P/F/C: 30/20/50 en\%) vs the previously offered normal protein diet (P/F/C: 15/35/50 en\%), and after the isoenergetic high-protein diet an ad libitum high-protein diet (P/F/C: 30/20/50 en\%). During the iso-energetic high-protein diet the subjects did not lose body weight whereas during the ad libitum high-protein diet they lost $4.9 \pm 0.5 \mathrm{~kg}$, with a decrease in FM by $3.7 \pm 0.4 \mathrm{~kg} .{ }^{25}$ Also Johnston et al. ${ }^{76}$ came to a similar conclusion, when they assigned healthy adults $(n=20)$ randomly to one of two low-fat ( $<30 \%$ energy), energy-restricted groups: high-protein (30\% energy) or highcarbohydrate (60\% energy). They controlled $24 \mathrm{~h}$ intakes during the 6 weeks trial. Both diets were equally effective at reducing body weight $(-6 \%, P<0.05)$ and FM $(-9$ to $-11 \%$, $P<0.05)$; however, subjects consuming the high-protein diet reported more satisfaction and less hunger in the first month of the trial. Both diets significantly lowered total cholesterol $(-10$ to $-12 \%)$, insulin $(-25 \%)$, and uric acid ( -22 to $-30 \%)$ concentrations in blood from fasting subjects. Urinary calcium excretion increased $42 \%$ in subjects consuming the high-protein diet, mirroring the 50\% increase in dietary calcium with consumption of this diet; thus, apparent calcium balance was not adversely affected. Creatinin clearance was not altered by diet treatments, and nitrogen balance was more positive in subjects consuming the highprotein diet vs the high-carbohydrate diet $(3.9 \pm 1.4$ and $0.7 \pm 1.7 \mathrm{gN} /$ day, respectively, $P<0.05){ }^{76}$ They concluded that low-fat, energy-restricted diets of varying protein content (15 or $30 \%$ energy) promoted healthful weight loss, but diet satisfaction was greater in those consuming the high-protein diet. ${ }^{76}$

Taken together, body-weight loss on a relatively highprotein diet appears to be greater under ad libitum energy 
intake conditions, leading to decreased energy intake that still includes a sufficient absolute amount of protein, suggesting that in addition to metabolic effects of protein on body-weight loss, energy intake plays an important role. This is underscored by the phenomenon that under isoenergetic conditions no statistically significant difference between body-weight loss on a high-protein or highcarbohydrate diet was shown. Moreover, most of the studies on protein intake in relation to body-weight management show an improved body composition (i.e. an increased FFM/ FM) and metabolic profile with a relatively high-protein diet, The relatively high protein negative energy balance diets all consist of $25-30 \%$ of energy from protein implying a sustained normal protein intake in grams whereas energy intake is decreased.

\section{Relatively high-protein diets for body-weight maintenance}

Observations on maintenance of body weight with a highprotein diet, after body-weight loss show that overweight to moderately obese men and women who consumed $18 \%$ of energy intake as protein, regained less weight, that is, $1 \mathrm{~kg}$, during 3 months after $7.5 \pm 2.0 \%$ body-weight loss over 4 weeks, compared to the $2 \mathrm{~kg}$ their counterparts who consumed $15 \%$ of energy intake as protein regained. The result was not owing to possible differences in dietary restraint or in physical activity between the high-protein and the control group, indicating a metabolic effect of protein. ${ }^{5}$

The composition of the body mass regained was more favorable in the additional protein group (i.e. no regain of FM, but only of FFM, resulting in a lower percentage body fat). ${ }^{5}$ Leptin concentrations from fasting blood samples during weight regain increased significantly slower in the additional-protein group, and only in the control group was the increase of leptin related to the increase of FM. Moreover, metabolic risk characteristics were reduced in the additional protein group. ${ }^{5}$ Energy efficiency (kilogram body-mass regain/EI) was significantly lower in the additional-protein group. Similar observations were reported by Lacroix et al., ${ }^{77}$ from a long-term high-protein diet that markedly reduced adipose tissue without major side effects in Wistar male rats. The observations with respect to energy efficiency during weight regain is comparable to the 'Stock hypothesis' described for weight gain. ${ }^{7}$ Satiety was higher on the highprotein diet, whereas there was no indication of a difference in the energy intake. ${ }^{5}$

With a similar design, after 6 months a weight maintenance of $0.8 \mathrm{~kg}$ (high-protein group) vs $3.0 \mathrm{~kg}$ weight regain $(P<0.05)$ was shown; 6 months later, when the follow-up took place, these figures were $1.0 \mathrm{~kg}$ vs $3.9 \mathrm{~kg}$ $(P<0.05){ }^{6}$

Taken together, evidence shows that a relatively increased protein intake did sustain weight maintenance by (i) favoring regain of FFM at the cost of FM at a similar physical activity level, (ii) reducing the energy efficiency with respect to the body mass regained and (iii) increasing satiety. ${ }^{5}$

\section{Conclusions}

The role of protein in body-weight regulation, in comparison to other macronutrients, consists of different aspects: (i) satiety, (ii) thermogenesis, (iii) energy efficiency and (iv) body composition. These aspects are partly related to each other.

First of all, protein appears to increase satiety when given iso-energetically. This phenomenon is used in reduced energy-intake diets, mainly in the ad libitum condition, in which sustained satiety is achieved with sustained absolute protein intake, despite lower energy intake. The highly satiating effect of protein has been observed in the postprandial as well as post-absorptive state. Post-prandially the type and source of protein may be of importance, but postabsorptively the satiating effect is still present with varying types and sources. Elevated thermogenesis and GLP-1 appear to play a role in protein-induced satiety.

Second, high-protein diets imply a high thermogenesis, with animal protein showing a higher thermogenesis than vegetable protein. In the longer term, this high thermogenesis contributes to the low energy-efficiency of protein. In the short-term a positive protein and a negative fat balance, through increased fat oxidation, was observed, which may support FFM sparing mechanisms.

Third, under conditions of slight body-weight regain (as aiming for weight maintenance), a high-protein diet shows reduced energy efficiency related to the body composition of the body weight regained, that is, in favor of FFM.

Fourth, during body-weight loss, as well as during weight regain, a high-protein diet preserves or increases FFM and reduces FM and improves the metabolic profile.

Finally, an absolute and relative protein needs to be discriminated, as protein intake is studied under various energy balances. An absolutely normal protein diet thus becomes a relatively high-protein diet in negative energy balance as well as at weight maintenance. Therefore, 'high protein negative energy balance diets' imply that the grams of proteins ingested are kept at the same level, that is, representing $10-15 \%$ of energy at energy balance, despite lower energy intakes.

\section{References}

1 Westerterp-Plantenga MS. Food intake, metabolism and obesity in humans. In: MJG Farthing, D Mahalanabis (eds). The control of food and fluid intake in health and disease. Nestle Nutrition Workshop series 2003; 51: 195-221.

2 Westerterp-Plantenga MS, Rolland V, Wilson SAJ, Westerterp KR. Satiety related to $24 \mathrm{~h}$ diet-induced thermogenesis during high 
protein/carbohydrate vs high fat diets measured in a respiration chamber. Eur J Clin Nutr 1999; 53: 495-502.

3 Lejeune MPGM, Westerterp KR, Adam TCM, Luscombe-Marsh ND, Westerterp-Plantenga MS. Ghrelin and glucagon-like peptide 1 concentrations, 24-h satiety, and energy and substrate metabolism during a high-protein diet and measured in a respiration chamber. Am J Clin Nutr 2006; 83: 89-94.

4 Jean $\mathrm{C}$, Rome S, Mathe Y, Tome D. Metabolic evidence for adaptation to a high protein diet in rats. J Nutr 2001; 131: 91-98.

5 Westerterp-Plantenga MS, Lejeune MPGM, Nijs I, van Ooijen M, Kovacs EMR. High protein intake sustains weight maintenance after body weight loss in humans. Int J Obes Rel Metab Disord 2004; 28: 57-64.

6 Lejeune MPGM, Kovacs EMR, Westerterp-Plantenga MS. Additional protein intake limits weight regain after weight loss in humans. Br J Nutr 2005; 93: 281-289.

7 Stock MJ. Gluttony and thermogenesis revisited. Int J Obes Rel Metab Disord 1999; 23: 1105-1117.

8 Dulloo AG, Jacquet J. Low-protein overfeeding: a tool to unmask susceptibility to obesity in humans. Int J Obes Rel Metab Disord 1999; 23: 1118-1121.

9 Pullar JD, Webster AJF. The energy cost of fat and protein disposition in the rat. Br J Nutr 1977; 37: 355-363.

10 Hall WL, Millward DJ, Long SJ, Morgan LM. Casein and whey exert different effect on plasma amino acid profiles, gastrointestinal hormone secretion and appetite. Br J Nutr 2003; 89: 239-248.

11 World Health Organ Tech Rep Ser. 2000. 894:i-xii, 1-253. Obesity: preventing and managing the global epidemic. Report of a WHO consultation.

12 Hulshof KFAM, Ocke MC, van Rossum CTM, Buurma-Rethans EJM, Brants HAM, Drijvers JJMM. Results of the food consumption survey 2003. Dutch; Resultaten van de voedselconsumptiepeiling 2003. RIVM/TNO, Bilthoven/Zeist, 2004.

13 Wright JD, Kennedy-Stephenson J, Wang CY, McDowell MA, Johnson CL. Trends in intake of energy and macronutrientsUnited States, 1971-2000. National Center for Health Statistics, CDC. JAMA 2004; 291: 1193-1194.

14 McLennan W, Podger A. National Nutrition Survey: nutrient intakes and physical measurements (Australian Bureau of Statistics). Australia 1998.

15 World Health Organisation. Nutrition profile of the WHO SouthEast Asia region, New Delphi 2000.

16 FAO Statistics Division. http://www.fao.org/es.ess.faostat/food security/index en.htm.

17 Wechsler JG, Wenzel H, Swobodnik W, Ditschuneit HH, Ditschuneit H. Nitrogen balance studies during modified fasting. Postgrad Med J 1984; 60 (Suppl 3): 66-73.

18 Ditschuneit HH. Ergebnisse ambulante Adipositastherapie mit verschiedenen proteïnereichen Diaeten. In: Ditschuneit $\mathrm{H}$, Wechsler JG (eds). Ergebnisse der Adipositasfotschung. perimed Fachbuch-Verlagsgesellschaft mbH: Erlangen, 1984; 171-178.

19 Latner JD, Schwartz M. The effects of a high-carbohydrate, high protein or balanced lunch upon later food intake and hunger ratings. Appetite 1999; 33: 119-128.

20 Eisenstein J, Roberts SB, Dallal G, Saltzman E. High-protein weight-loss diets: are they safe and do they work? A review of experimental and epidemiologic data. Nutr Rev 2002; 60: 189-200.

21 Westerterp-Plantenga MS, Westerterp KR, Rubbens M, Richalet J-P. Appetite at 'high altitude'; operation Everest-Comex: a simulated ascent of the Mt. Everest. J Appl Physiol 1999; 87: 391-399.

22 Billeaud C, Guillet J, Sandler B. Gastric emptying in infants with or without gastro-oesophageal reflux according to the type of milk. Eur J Clin Nutr 1990; 4: 577-583.

23 Boirie Y, Dangin M, Gachon P, Vasson MP, Maubois JL, Beaufrere B. Slow and fast dietary proteins differently modulate postprandial protein accretion. Proc Natl Acad Sci USA 1997; 94: 14930-14935.
24 Dangin M, Boirie Y, Garcia-Rodenas C, Gachon P, Fauquant J, Callier $\mathrm{P}$ et al. The digestion rate of protein is an independent regulating factor of postprandial protein retention. Am J Physiol Endocrinol Metab 2001; 280: E340-E348.

25 Weigle DS, Breen PA, Matthys CC, Callahan HS, Meeuws KE, Burden VR et al. A high protein diet induces sustained reductionist in appetite, ad libitum caloric intake, and body weight despite compensatory changes in diurnal plasma leptin and ghrelin concentratieons. Am J Clin Nutr 2005; 82: 41-48.

26 Bensaid A, Tome D, Gietzen D. Protein is more potent than carbohydrate for reducing appetite in rats. Physiol Behav 2002; 75 577-582.

27 Bensaid A, Tome D, L'Heureux-Bourdon D, Even P. A high-protein diet enhances satiety without conditioned taste aversion in the rat. Physiol Behav 2003; 78: 311-320.

28 Livesey G. A perspective on food energy standards for nutrition labelling. Br J Nutr 2001; 85: 271-287.

29 Tappy L. Thermic effect of food and sympathetic nervous system activity in humans. Reprod Nutr Dev 1996; 36: 391-397.

30 Westerterp KR, Wilson SAJ, Rolland V. Diet induced thermogenesis measured over $24 \mathrm{~h}$ in na respiration chamber: effect of diet composition. Int J Obes 1999; 23: 287-292.

31 Tessari P, Kiwanuka E, Zanetti M, Barazzoni R. Postprandial body protein synthesis and amino acid catabolism measured with leucine and phenylalanine-tyrosine tracers. Am J Physiol Endocrinol Metab 2003; 284: E1037-E1042.

32 van Milgen J. Modeling biochemical aspects of energy metabolism in mammals. J Nutr 2002; 132: 3195-3202.

33 Pannemans DL. Effect of protein source and quantity on protein metabolism in elderly women. Am J Clin Nutr 1998; 68: 1228-1235.

34 Mikkelsen PB, Toubro S, Astrup A. Effect of fat-reduced diets on $24 \mathrm{~h}$ energy expenditure: comparisons between animal protein, vegetable protein, and carbohydrate. Am J Clin Nutr 2000; 72: $1135-1141$.

35 Boirie Y. Slow and fast dietary proteins differently modulate postprandial protein accretion. Proc Natl Acad Sci USA 1997; 94: 14930-14935.

36 Dangin $\mathrm{M}$. The digestion rate of protein is an independent regulating factor of postprandial protein retention. Am J Physiol Endocrinol Metab 2001; 280: E340-E348.

37 Dangin M. Influence of the protein digestion rate on protein turnover in young and elderly subjects. I Nutr 2002; 132: 3228S-3233S

38 Stryer L. Biochemistry. W.H. Freeman and Company: New York, 1988.

39 Azzout B, Chanez M. Gluconeogenesis from dihydroxyacetone in rat hepatocytes during the shift from a low protein, high carbohydrate to a high protein, carbohydrate-free diet. $J$ Nutr 1984; 114: 2167-2178.

40 Bois-Joyeux B, Chanez M. Comparison between starvation and consumption of a high protein diet in rats: hepatic metabolites and amino acid levels during the first $24 \mathrm{~h}$. Diabete Metab 1986; 12: $239-245$.

41 Kaloyianni M, Freedland RA. Contribution of several amino acids and lactate to gluconeogenesis in hepatocytes isolated from rats fed various diets. J Nutr 1990; 120: 116-122.

42 Bois-Joyeux B, Chanez M. Studies on the early changes in rat hepatic fructose 2,6-bisphosphate and enzymes in response to a high protein diet. $J$ Nutr 1986; 116: 446-454.

43 Peret J, Chanez M. Effects of quantity and quality of dietary protein and variation in certain enzyme activities on glucose metabolism in the rat. J Nutr 1975; 105: 1525-1534.

44 Azzout-Marniche D, Gaudichon C, Blouet C, Mathe V, Bos C, Huneau JF et al. Glucoregulation in rat adapted to a hight protein diet. Exp Biol, FASEB Journal (abstract) 2005; 19: A74.

45 Seoane J, Trinh K. Metabolic impact of adenovirus-mediated overexpression of the glucose-6-phosphatase catalytic subunit in hepatocytes. J Biol Chem. 1997; 272: 26972-26977. 
46 Trinh K, O'Doherty RM. Perturbation of fuel homeostasis caused by overexpression of the glucose-6-phosphatase catalytic subunit in liver of normal rats. J Biol Chem 1998; 273 : 31615-31620.

47 Mithieux G, Misery P. Portal sensing of intestinal gluconeogenesis is a mechanistic link in the diminution of food intake induced by diet protein. Cell Metab 2005; 2: 321-329.

48 L'Heureux-Bouron D, Tome D. A very high $70 \%$ protein diet does not induce conditioned taste aversion in rats. J Nutr 2004; 134: $1512-1515$.

49 Watford M. Is the small intestine a gluconeogenic organ. Nutr Rev 2005; 63: 356-360.

50 Lin B, Annabi B. Cloning and characterization of cDNAs encoding a candidate glycogen storage disease type $1 \mathrm{~b}$ protein in rodents. J Biol Chem 1998; 273: 31656-31660.

51 Guionie $\mathrm{O}$, Clottes E. Identification and characterisation of a new human glucose-6-phosphatase isoform. FEBS Lett 2003; 551: 159-164.

52 Pillot B, Misery P, Zitoun C, Rajas F, Mithieux G Les protéines alimentaires modifient la répartition interorgane de la production de glucose (PEG) Journée Laennec du 13 décembre 2005.

53 Habold C, Foltzer-Jourdainne C. Intestinal gluconeogenesis and glucose transport according to body fuel availability in rats. J Physiol 2005; 566 (Part 2): 575-586 Epub 2005 May 5.

54 Rajas F, Bruni N. The glucose- 6 phosphatase gene is expressed in human and rat small intestine: regulation of expression in fasted and diabetic rats. Gastroenterology 1999; 117: 132-139.

55 Mithieux G, BadyI. Induction of control genes in intestinal gluconeogenesis is sequential during fasting and maximal in diabetes. Am J Physiol Endocrinol Metab 2004; 286: E370-5 Epub 2003 Oct 14

56 Calbet JA, MacLean DA. Plasma glucagon and insulin responses depend on the rate of appearance of amino acids after ingestion of different protein solutions in humans. J Nutr 2002; 132: 2174-2182.

57 van Loon LJ, Saris WH, Verhagen $H$, Wagenmakers AJ. Plasma insulin responses after ingestion of different amino acid or protein mixtures with carbohydrate. Am J Clin Nutr 2000; 72: 96-105.

58 Biolo G, Tipton KD, Klein S, Wolfe RR. An abundant supply of amino acids enhances the metabolic effect of exercise on muscle protein. Am J Physiol 1997; 273: E122-E129.

59 Biolo G, Williams BD, Fleming RY, Wolfe RR. Insulin action on muscle protein kinetics and amino-acid transport during recovery after resistance exercise. Diabetes 1999; 48: 949-957.

60 Biolo G, Maggi SP, Williams BD, Tipton KD, Wolfe RR. Increased rates of muscle protein turnover and amino acid transport after resistance exercise in human. Am J Physiol 1995; 268: E514-E520.

61 Phillips SM, Tipton KD, Aarsland A, Wolf SE, Wolfe RR. Mixed muscle protein synthesis and breakdown after resistance exercise in humans. Am J Physiol 1997; 273: E99-E107.

62 Layman DK. The role of leucine in weight loss diets and glucose homeostasis. J Nutr 2003; 133: 261S-267S.
63 Kimball SR, Jefferson LS. Regulation of protein synthesis by branched-chain amino acids. Curr Opin Clin Nutr Metab Care 2001; 4: 39-43.

64 Sherwin RS. Effect of starvation on the turnover and metabolic response to leucine. J Clin Invest 1978; 61: 1471-1481.

65 Piatti PM, Monti F, Fermo I, Baruffaldi L, Nasser R, Santambrogio $\mathrm{G}$ et al. Hypocaloric high-protein diet improves glucose oxidation and spares lean body mass: comparison to hypocaloric highcarbohydrate diet. Metabolism 1994; 43: 1481-1487.

66 Baba NH, Sawaya S, Torbay N, Habbal Z, Azar S, Hashim SA. High protein vs high carbohydrate hypo-energetic diet for the treatment of obese hyperinsulinemic subjects. Int J Obes Relat Metab Diord 1999; 23: 1202-1206.

67 Farnsworth E, Luscombe ND, Noakes M, Wittert G, Argyiou E, Clifton PM. Effect of a high-protein, energy-restricted diet on body composition, glycemic control, and lipid concentrations in overweight and obese hyperinsulinemic men and women. Am Clin Nutr 2003; 78: 31-39.

68 Layman DK, Shiue H, Sather C, Erickson DJ, Baum J. Increased dietary protein modifies glucose and insulin homeostasis in adult women during weight loss. J Nutr 2003; 133: 405-410.

69 Samaha FF, Iqbal N, Seshadri P, Chicano KL, Daily DA, McGrory J et al. A low-carbohydrate as compared with a low-fat diet in severe obesity. N Engl J Med 2003; 348: 2074-2081.

70 Brinkworth GD, Noakes M, Keogh JB, Luscombe ND, Wittert GA, Clifton PM. Long-term effects of a high-protein, low-carbohydrate diet on weight control and cardiovascular risk markers in obese hyperinsulinemic subjects. Int J Obes Relat Metab Disord 2004; 28: 661-670.

71 Brehm BJ, Seeley RJ, Daniels SR, D'Alessio DA. A randomized trial comparing a very low carbohydrate diet and a calorie-restricted low fat diet on body weight and cardiovascular risk factors in healthy women. J Clin Endocrinol Metab 2003; 88: 1617-1623.

72 Skov AR, Toubro S, Ronn B, Astrup A. Randomized trial on protein vs carbohydrate in ad libitum fat reduced diet for the treatment of obesity. Int J Obes Rel Metab Disord 1999; 23: 528-536.

73 Due A, Toubro S, Skov AR, Astrup A. Effect of normal-fat diets, either medium or high in protein, on body weight in overweight subject: a randomised 1-year trial. Int J Obes Rel Metab Disord 2004; 28: 1283-1290.

74 Dumesnil JG, Turgeon J, Tremblay A. Effect of a low-glycemic index-low-fat-high protein diet on the atherogenic metabolic risk profile of abdominally obese men. Br J Nutr 2001; 86: 57-568.

75 Laymen DK, Boileau RA, Erickson DJ. A reduced ratio of dietary carbohydrate to protein improves body-composition and blood lipid profiles during weight loss in adult women. J Nutr 2003; 133: 411-417.

76 Johnston CS, Tjonn SL, Swan PD. High-protein, low fat diets are effective for weight loss and favorably alter biomarkers in healthy adults. J Nutr 2004; 134: 586-591.

77 Lacroix M, Gaudichon C, Martin A, Morens C, Mathe V, Tome D et al. A long-term high-protein diet markedly reduces adipose tissue without major side effects in Wistar male rats. Am I Physiol Regul Integr Comp Physiol 2004; 287: R934-R942. 